\title{
PEMANFAATAN TEPUNG KULIT PEPAYA (Carica papaya L) DALAM RANSUM TERHADAP KUALITAS INTERNAL TELUR
}

\author{
Armando Paat, C.L. Sarajar, J. R. Leke*, F. N. Sompie \\ Fakultas Peternakan, Universitas Sam Ratulangi Manado, 95115.
}

\begin{abstract}
ABSTRAK
Penelitian ini bertujuan untuk mengetahui manfaat tepung kulit pepaya (Carica papaya $L$ ) dalam ransum terhadap kualitas internal telur ayam MB 402. Materi yang digunakan dalam penelitian ini yaitu 100 ekor ayam petelur MB 402. Rancangan penelitian penelitian yang digunakan Rancangan Acak Lengkap dengan 5 perlakuan dan 5 ulangan. tiap ulangan terdapat 4 ekor ayam petelur MB 402. Peubah yang diamati pada penelitian ini meliputi bobot telur, bobot kuning telur, dan warna kuning telur. Hasil penelitian menunjukkan bahwa pemberian tepung kulit pepaya (Carica pepaya L) sampai $16 \%$ dalam pakan ayam petelur MB 402 terhadap bobot telur, bobot kuning telur dan warna kuning telur berbeda tidak nyata $(\mathrm{P}>0,05)$. Bedasarkan hasil penelitian ini dapat disimpulkan bahwa penggunaan tepung kulit pepaya sampai $16 \%$ dapat menghasilkan kualitas produk ayam petelur MB 402.
\end{abstract}

Kata Kunci: Tepung kulit pepaya, ransum petelur, kualitas internal telur

\section{ABSTRACK}

\section{UTILIZATION}

AND

INTERNAL QUALITY OF EGG ON PAPAYA PEEL MEAL DIET (CARICA

PAPAYA L). The aim of research was to utilization and internal quality of eggs on

\footnotetext{
*Korespondensi (corresponding author):
}

Email: rinileke@unsrat.ac.id papaya (carica papaya $L$ ) peel meal diet. The material used in this study were one hundred laying hens (MB 402). The completely randomized design (CRD) was done in this research for analysing of statistics to five treatments and four replications, each replications was occupied by five laying hens (MB 402). The variable measured were egg weight, egg yolk, colour of egg yolk. The result of this research showed that egg weight, egg yolk, the colour egg yolk was not significantly different ( $>>0.05)$. Conclusion, the utilization of flour skin papaya until $16 \%$ in feed will increase the quality of chicken eggs.

Kata Kunci: Papaya peel meal, laying feed, the internal quality of egg.

\section{PENDAHULUAN}

Kondisi adanya wabah virus corona (Covid 19) pada awal tahun 2020 mendorong masyarakat membutuhkan makanan bergizi sehingga terus mengalami peningkatan salah satunya telur. Telur unggas (ayam) mempunyai kandungan vitamin, asam amino esensial dan non esensial yang cukup lengkap dan merupakan salah satu sumber penghasil protein hewani tertinggi sehingga sangat cocok untuk memenuhi kebutuhan tubuh manusia. Vitamin larut di lemak A 150 - 
400 IU, D 20 - 80 IU, E 0,6 - 2 (mg), K 0,01-0,03 mg (Yuwanta, 2010). Telur

Pengukuran kualitas telur menurut USDA dilakukan melalui pengukuran kualitas internal dan external telur dengan nilai standart kualitas AA, A, dan B serta kotor. Kualitas telur meliputi pengukuran kualiats internal dan external (Stadelman and Cotteriil, 1997; Monira et al., 2003; Parmar et al., 2006). Telur merupakan produk yang digemari oleh konsumen, serta merupakan bahan pangan yang lengkap kandungan gizinya dan mudah dicerna. Guna menghasilkan telur yang berkualitas dibutuhkan pakan berkualitas yang disusun dari bahan-bahan yang kecil kemungkinan bersaing dengan kebutuhan manusia, diantaranya kulit buah pepaya. Kulit buah pepaya merupakan limbah dari buah pepaya yang memiliki kandungan zat-zat makanan yang cukup tinggi. Peneltian penggunaan tepung kulit pepaya (Carica papaya $L$ ) sampai $12 \%$ dapat digunakan dalam pakan ayam petelur dan tidak memberikan efek negatif pada kualitas telur. Tepung kulit buah pepaya mengandung protein yang tinggi, yaitu $25,74 \%$ dan serat kasar 20,06\%, lemak 4,52\%, Kalsium 1,12\%, fosfor $0,47 \%$, energi metabolis $2997.6 \mathrm{Kkal} / \mathrm{kg}$ (Leke et al., 2019). Kulit buah pepaya juga mengandung folat, vitamin A, magnesium, tembaga, asam pantotenat, fiber.3, vitamin B kompleks, beta karoten, lutein, zeaxanthan, vitamin E, kalsium, kalium, vitamin $K$, lycopene, dan enzim papain.

Berdasarkan nilai gizi kulit buah pepaya, diharapkan dapat digunakan sebagai bahan penyusun atau pengganti sebagian ransum ternak unggas. Tanaman buah pepaya mudah dibudidayakan, tumbuh di daerah dataran rendah dan dataran tinggi. Di Indonesia, tanaman pepaya dapat tumbuh dari dataran rendah sampai daerah pegunungan $1000 \mathrm{~m}$ dari permukaan laut. Pepaya berasal dari Meksiko bagian selatan dan bagian utara Amerika Selatan. Tanaman ini menyebar ke benua Afrika dan Asia serta India.

Produksi pepaya pada tahun 2014 sebesar 44.678 atau 29,47 persen dan pada tahun 2015, yaitu sebesar 47,352 ton atau 31,13\% (Badan Pusat Statistik, 2015) Berdasarkan data-data produksi tersebut menunjukkan bahwa buah pepaya memiliki potensi. Kulit buah pepaya merupakan limbah yang tidak digunakan dan terbuang yang akhirnya dapat mencemari lingkungan. Leke et al. (2019) dalam penelitian karakteristik nutrisi dan kualitas telur ayam yang diberi tepung kulit pepaya sampai 12 persen dalam ransum tidak memberikan efek negative terhadap ayam petelur.

Bertolak dari pemikiran tersebut di atas maka telah dilakukan penelitian dengan maksud untuk mengetahui sampai sejauh mana level pemberian limbah kulit 
buah pepaya dalam ransum dan bagaimana pengaruhnya terhadap kualitas internal telur ayam ras.

\section{MATERI DAN METODE PENELITIAN}

\section{Proses Pembuatan Tepung Pepaya}

Buah pepaya diambil dari Desa Tatelu Kabupaten Minahasa Utara. Buah pepaya yang diambil dicuci dulu dengan air, dikemudian diambil bagian kulit pepaya berwarna hijau. Kulit pepaya dipotong menjadi bagian bagian kecil 2-3 $\mathrm{cm}$, kemudian dilakukan melalui kering sinar matahari 4-5 hari hingga kering. Satu buah pepaya seberat $3,7 \mathrm{~kg}$, menghasilkan 226,79 gram tepung kulit pepaya. Tepung kulit pepaya selama penelitian yang digunakan sebanyak $50 \mathrm{~kg}$ tepung kulit papaya.

\section{Ternak Percobaan}

Ternak yang digunakan dalam penelitian ini, yaitu ayam ras petelur fase layer strain MB 402 umur 42 minggu sebanyak 100 ekor. Kandang yang digunakan dalam penelitian ini, adalah kandang sistim baterei dengan ukuran $60 \mathrm{x}$ 30 x $35 \mathrm{~cm}$. Setiap unit kandang dilengkapi dengan tempat makan dan minum.

\section{Ransum}

Ransum yang digunakan disusun setiap hari dengan jumlah sesuai dengan kebutuhan umur ayam petelur. Ransum diberikan 2 kali yaitu 08.00 pagi dan 14.00 siang. Bahan penyusun ransum kontrol yaitu terdiri dari Tabel 1 menunjukan komposisi zat-zat makanan ransum percobaan. Tabel 2 menunjukkan susunan bahan penyusun ransum perlakuan/kontrol. Tabel 3 komposisi ransum percobaan, sedangkan Tabel 4 komposisi zat-zat makanan ransum percobaan.

\section{Metode Penelitian}

Rancangan yang digunakan adalah Rancangan Acak Lengkap (RAL) menurut petunjuk Steel dan Torrie (1994). Perlakuan yang digunakan 5 perlakuan dan 5 ulanagan, sehingga terdapat 25 unit perlakuan, dimana pada masing masing unit terdiri dari 4 ekor ayam petelur MB 402, sehingga jumlah ayam adalah 100 ekor. Perlakuan ransum disusun berdasarkan kebutuhan ayam petelur berdasarkan iso kalori dan iso energi. Perlakuan yang disusun sebagai berikut :

$$
\begin{aligned}
& \mathrm{R} 0=\text { Ransum tanpa menggunakan tepung } \\
& \text { kulit pepaya (TKP) } \\
& \mathrm{R} 1=\text { Ransum kontrol } 96 \%+4 \% \text { TKP } \\
& \mathrm{R} 2=\text { Ransum kontrol } 92 \%+8 \% \text { TKP } \\
& \mathrm{R} 3=\text { Ransum kontrol } 88 \%+12 \% \text { TKP } \\
& \mathrm{R} 4=\text { Ransum kontrol } 84 \%+16 \% \text { TKP }
\end{aligned}
$$


Tabel 1. Komposisi Zat-Zat Makanan Ransum Percobaan.

\begin{tabular}{lcccccc}
\hline \multirow{2}{*}{ Bahan Makanan } & $\begin{array}{c}\text { Krotein } \\
(\%)\end{array}$ & $\begin{array}{c}\text { Lemak } \\
(\%)\end{array}$ & $\begin{array}{c}\text { Serat Kasar } \\
(\%)\end{array}$ & $\begin{array}{c}\text { Ca } \\
(\%)\end{array}$ & $\begin{array}{c}\text { P } \\
(\%)\end{array}$ & $\begin{array}{c}\text { EM } \\
(\text { Kcal/kg) }\end{array}$ \\
\hline Jagung kuning $^{1}$ & 8,8 & 3,9 & 2 & 0,02 & 0,28 & 3350 \\
Dedak halus $^{1}$ & 12 & 13 & 12 & 0,12 & 0,5 & 1630 \\
Tepung ikan $^{2}$ & 60 & 9 & 1 & 5,5 & 0,3 & 2830 \\
CaC03 $^{2}$ & - & - & - & 29,4 & - & - \\
Konsentrat Cal 9.36 $^{2}$ & 29 & 10 & 7 & 3 & 2 & 2600 \\
Tepung kulit pepaya & 25,74 & 4,52 & 20,06 & 1,12 & 0,47 & 2997,6 \\
\hline Keterangan : ${ }^{3}$ NRC (1994) & & & & & \\
& ${ }^{2}$ Sumber PT. Japfa & & & & &
\end{tabular}

Tabel 2. Komposisi Ransum Kontrol

\begin{tabular}{lc}
\hline Bahan Makanan & Komposisi (\%) \\
\hline Jagung & 52 \\
Dedak & 14 \\
Tepung ikan & 7 \\
$\mathrm{CaCO}_{3}$ & 3 \\
Konsentrat & 24 \\
\hline Jumlah & 100 \\
\hline
\end{tabular}

Tabel 3. Komposisi Ransum Percobaan

\begin{tabular}{llllll}
\hline \multirow{2}{*}{ Bahan Makanan } & \multicolumn{5}{c}{ Perlakuan } \\
\cline { 2 - 6 } & R0 & R1 & R2 & R3 & R4 \\
\hline Ransum Kontrol & 100 & 96 & 96 & 94 & 92 \\
Tepung kulit pisang & 0 & 4 & 8 & 12 & 16 \\
\hline Total & 100 & 100 & 100 & 100 & 100 \\
\hline
\end{tabular}

Tabel 4. Komposisi zat-zat makanan ransum percobaan

\begin{tabular}{llllll}
\hline Komposisi Zat & \multicolumn{5}{c}{ Perlakuan } \\
\cline { 2 - 6 } Makanan & $\mathrm{R} 0$ & $\mathrm{R} 1$ & $\mathrm{R} 2$ & $\mathrm{R} 3$ & $\mathrm{R} 4$ \\
\hline Protein $(\%)$ & 16,38 & 17.74 & 18,07 & 18,41 & 18,74 \\
Lemak (\%) & 6,77 & 6.78 & 6,69 & 6,59 & 6,5 \\
Serat Kasar (\%) & 4,49 & 5,1 & 5,72 & 6,34 & 6,69 \\
Kalsium (\%) & 1,89 & 1,96 & 1,92 & 1,89 & 1,85 \\
Fosfor $(\%)$ & 0,71 & 0,7 & 0,69 & 0,68 & 0,67 \\
EM(Kcal/kg) & 2802,7 & 2800,51 & 2828,72 & 2816,94 & 2825,15 \\
\hline
\end{tabular}


Setiap perlakuan memiliki 5 ulangan, dan setiap ulangan/unit kandang percobaan ditempati 4 ekor ayam.

\section{Variabel Penelitian}

\section{Bobot Telur (g)}

Bobot telur (BT) merupakan perbandingan antara jumlah bobot telur yang dihasilkan (g) dengan jumlah telur yang dihasilkan (butir) atau dengan rumus sebagai berikut (North dan Bell, 1994)

$$
B T=\frac{\text { Jumlah bobot telur yang dihasilkan (g) }}{\text { Jumlah telur yang dihasilkan (butir) }}
$$

\section{Bobot Kuning Telur (g)}

Bobot kuning telur diukur dengan menimbang setiap kuning telur (Stadelman dan Cotteril, 1994). Pengukurannya dilakukan dengan menggunakan penimbangan berat kuning telur (g) setelah dipisahkan dari putih telur.

\section{Warna kuning telur}

Warna telur diperoleh dengan cara membandingkan warna kuning telur dengan Roche Yolk Colour Fan pada skala 1-16 (North dan Bell, 1994). Apabila terjadi perbedaan antar perlakuan dilakukan uji jarak berganda Duncan's (Steel dan Torrie, 1995).

\section{HASIL DAN PEMBAHASAN}

Pengaruh perlakuan penggunaan tepung kulit pepaya terhadap bobot telur, bobot kuning telur, dan warna kuning telur disajikan pada Tabel 5.

\section{Bobot Telur}

Rata-rata bobot telur dari masingmasing perlakuan seperti terlihat pada Tabel 5, berkisar antara 59,24 - 61,75 g. Telur yang dihasilkan pada penelitian ini digolongkan pada kelompok telur ukuran large (kisaran 57,40 -69,64 g/butir). Abiola et al. (2008) dalam penelitian kategori telur dibagi 3 kategori size yaitu small (41,09$50,97 \mathrm{~g})$, medium $(50,98-57,39 \mathrm{~g})$ dan large $(57,40-69,64 \mathrm{~g})$.

Hasil analisis sidik ragam menunjukan bahwa penggunaan tepung kulit pepaya dalam ransum sampai $16 \%$ tidak menyebabkan perbedaan yang nyata terhadap bobot telur. Hal ini menunjukan bahwa dari segi kualitas ransum dalam menggunakan tepung kulit papaya (R1- R4) dengan yang tanpa tepung kulit papaya (R0) sama, sehingga dapat memenuhi kebutuhan gizi. Kualitas ransum yang dikonsumsi ternak termasuk ayam dapat mempengaruhi produk yang dihasilkan. Pemenuhan pakan yang dikonsumsi sangat berguna untuk hidup pokok dan produksi telur. Telur merupakan hasil produksi dari ayam, sangat mempengaruhi bobot telur yaitu umur ayam, pakan, suhu lingkungan, strain ayam, bobot induk, periode bertelur dan penyakit. Veena et al. (2015) 
mengemukakan bahwa faktor faktor yang mempengaruhi kualitas telur yaitu umur ayam, iklim, lingkungan, nutrisi. Tepung Kulit pepaya merupakan limbah yang dapat mendukung untuk digunakan sebagai bahan pakan ayam. Menurut Ayoola dan Adeyeye (2010) dalam pepaya kering dapat digunakan sebagai obat herbal, sumber phytochemical, dan sebagai sumber pakan karena mengandung zat pakan, vitamin dan mineral yang cukup baik. Sumber mineral dan vitamin dalam pakan akan memberikan bobot telur yang kualitas lebih baik. Konsumsi energi dan protein yang rendah akan mengakibatkan kualitas produksi rendah (Roxana and Usturoi, 2012).

Bobot telur ditentukan oleh kualitas telur, besarnya telur, dan besar telur ditentukan oleh faktor genetik, tingkat dewasa kelamin, umur dan obat-obatan. Ransum yang mempunyai kualitas baik akan menghasilkan telur yang besar. penurunan bobot telur dapat terjadi karena kandungan asam amino dalam ransum tidak sesuai dengan kebutuhan (Wahju, 1992).
Bobot telur dipengaruhi oleh kualitas bibit (genetik) dan kualitas ransum yang diberikan, disamping faktor-faktor lainnya. Besar kecilnya ukuran telur unggas sangat dipengaruhi oleh kandungan protein dan asam amino essensial dalam pakan (Latifah, 2007).

\section{Bobot kuning telur}

Rataan bobot kuning telur masingmasing perlakuan berkisar antara 16,9218,03 g. Hasil penelitian bobot kuning telur lebih tinggi dari penelitian Tugiyanti dan Iriyanti (2012) bahwa ayam petelur menghasilkan (bobot telur berkisar antara $54,03-58,55 \mathrm{~g}$, bobot kuning telur sebesar $12,32-13,39 \mathrm{~g}$.

Hasil analisis sidik ragam menunjukkan bahwa pengaruh penggunaan tepung kulit pepaya pada level $4 \%-16 \%$ memberikan pengaruh yang berbeda tidak nyata $(\mathrm{P}>0.05)$ terhadap bobot kuning telur ayam ras petelur. Sihombing et al. (2006), bobot kuning telur dalam telur dan ukuran besar kecilnya dipengaruhi oleh komsumsi

Tabel 5. Pengaruh Perlakuan Tepung Kulit Pepaya Dalam Ransum Terhadap Bobot Telur, Bobot Kuning Telur, Dan Warna Kuning Telur

\begin{tabular}{lccccc}
\hline \multirow{2}{*}{ Parameter } & \multicolumn{5}{c}{ Perlakuan } \\
\cline { 2 - 6 } & $\mathrm{R}_{0}$ & $\mathrm{R}_{1}$ & $\mathrm{R}_{2}$ & $\mathrm{R}_{3}$ & $\mathrm{R}_{4}$ \\
\hline Bobot telur $(\mathrm{g})$ & 59,24 & 59,36 & 60,26 & 59,44 & 61,75 \\
Bobot kuning telur $(\mathrm{g})$ & 16,92 & 17,73 & 17,35 & 17,22 & 18,03 \\
Warna kuning telur & 9,52 & 9,97 & 10,11 & 10,22 & 10,34 \\
\hline
\end{tabular}


protein. Selain itu bobot kuning telur dipengaruhi oleh komsumsi ransum, apabila komsumsi ransum rendah maka akan terbentuk kuning telur yang kecil dan sebaliknya jika komsumsi protein tinggi maka akan terbentuk kuning telur yang lebih besar.

Grobas et al. (2001), Senkoylu et al. (2004), dan Bohnzack et al. (2007) mengemukakan bahwa sumber asam lemak jenuh dalam pakan yang melalui absorbsi dalam pembuluh darah akan meningkatkan bobot kuning telur. Kuning telur dan albumen merupakan komponen terbesar di dalam telur yang secara langsung menentukan bobot telur yang dihasilkan.

\section{Warna kuning telur}

Rataan R0 - R4 warna kuning telur masing-masing perlakuan berkisar antara 9,52-10,34. Hasil penelitian ini lebih tinggi dari Penelitian Timbuleng et al. (2015) warna kuning telur ayam petelur MB 402 yaitu 7,95-9,08.

Hasil sidik ragam menunjukkan bahwa pemberian tepung kulit pepaya sampai $16 \%$ memberikan pengaruh yang tidak berbeda nyata $(\mathrm{P}>0.05)$.

Penelitian Murharlien dan Nurgiartiningsih (2015) bahwa pemberian daun pepaya dalam bentuk juice perlakuan $(0 \%, 4 \%$, dan 6\%) tidak memberikan perbedaan yang nyata terhadap warna kuning telur. Warna kuning telur merupakan salah satu kriteria tentang kualitas isi telur, warna kuning telur yang baik bervariasi antara 9-10 pada skala roche, rata rata telur beredar di pasaran adalah 8, sementara di Eropa menginginkan nilai 10-11 roche. Manipulasi pakan sering digunakan untuk meningkatkan warna kuning telur, warna kuning telur ditentukan oleh pakan yang mengandung pakan karatenoid yang mempunyai struktur seperti vitamin A. Unggas yang mengkonsumsi pigmen karotenoid lebih tinggi akan menghasilkan intensitas warna kuning telur yang lebih tinggi (Yuwanta, 2010). Kandungan karotenoid pada buah pepaya (carica papaya $L$ ) 13,8 $\mu \mathrm{g} / \mathrm{g}$ berat segar (Gross, 1991).

Telur yang dihasilkan oleh ayam berproduksi tinggi bagian kuning telurnya berwarna lebih mudah daripada telur yang berasal dari ayam berproduksi rendah. Warna kuning telur disebabkan oleh adanya kandungan karoten yang diperoleh dari pakan pada kuning telur tersebut. Semakin tinggi kandungan karoten akan menyebabkan warna kuning telur semakain tua. Karoten banyak terkandung dalam pigmen xanthophyll. Warna kuning telur sangat erat kaitannya dengan vitamin A yang terdapat di dalam pakan sehingga semakin besar karoten yang akan terdeposisi dalam kuning telur yang akhirnya akan mempengaruhi warna kuning telur. Semakin banyak kandungan 
vitamin A dalam ransum yang diberikan kepada unggas yang sedang bertelur, maka kualitas vitamin A dalam kuning telur semakin baik (Yuwanta, 2010). Semakin kuning ke orange dari warna kuning telur berasal dari bahan pakan hijuan dan jagung kuning. Castellini et al. (2006) mengemukakan bahwa Pigmen kuning telur berasal dari sumber karoten dan riboflavin yang diklasifikasi sebagai lipokrom dan liokrom. Warna kuning telur dipengaruhi oleh karotenoid dalam bentuk karoten dan xantofil. Sumber hijuan segar dan yang berasal dari bahan berwarna hijuan baik segar dan kering akan memberikan warna kuning lebih menarik. Apabila pakan mengandung lebih banyak karoten, yaitu xantofil, maka warna kuning telur semakin berwarna jingga kemerahan (Yamamoto et al., 2007)

Penggunaan tepung kulit pepaya dalam ransum sangat penting dan bermanfaat terhadap warna kuning telur karena pemberian tepung kulit pepaya dapat meningkatkan warna kuning telur, walaupun berdasarkan analisis keragaman tidak berbeda nyata $(\mathrm{P}>0,05)$ terhadap warna kuning telur.

\section{KESIMPULAN}

Penggunaan tepung kulit pepaya (TKP) sampai $16 \%$ dapat menghasilkan kualitas produk ayam petelur MB 402.

\section{DAFTAR PUSTAKA}

Abiola, S.S., O.O. Meeshioye, B.O Oyerinde, dan M.A. Bamgbose. 2008. Effect of egg size on hatchability of broiler chicks. Archieve Zootec 57(217): 83- 86.

Ayoola, B.P. dan A. Adeyeye. 2010. Phytochemical and nutrient evaluation of Carica papaya (Paw Paw) leafes. IJRRAS. 5: 325-328.

Badan Pusat Statistik. 2015. Propinsi Sulawesi Utara.

Bohnzack, C.R., R.H. Hams, V.D. Merkel, dan G.B. Russell. 2002. Performance of commercial layers when fed diets with four levels of corn oil or poultry fat. Journal Applied Poultry Research 11:68-76

Castellini, C., F. Perella, C. Mugnai, dan A. Dal Bosco. 2006. Welfare, productivity and quality traits of egg in laying hens reared under different rearing systems. National Journal of Animal Science 54(2): 147-155

Etches, R.J. 1996. Reproduction in Poultry. Department of Animal Science and Poultry Science. University of Guelph. Guelph Ontario Canada NIG 2W1. Cab International. P. 286-297.

Grobas, S., G.G. Mateos, dan J. Mendez. 1999. Influence of dietary linoleic acid on production and weight of eggs and egg components in young brown hens. Journal of Applied Poultry Research. 8(2): 177-184 
Gross, Jeana. 1991. Pigments In Vegetables (Chlorophylls And Carotenoids). Van Nostrand Reinhold. New York. 7. 75.

Leke, J.R., F.N. Sompie, E. Wantasen, T.E Tallei. 2019. Nutritional characteristics and quality of eggs from laying hens fed on papaya peel meal diet. J. Animal Production 20(3):147-154.

Latifah, R. 2007. The increasing of afkir duck's egg quality with pregnant mare"s serum gonadotropin (PMSG) hormones. Jurnal Protein 14(1):21-30.

Monira, K.N., M. Salahuddin, dan G. Miah, 2003. Effect of breed and holting period on egg quality characteristics of chicken. Journal of Poultry Science 2(4):261-263.

Murharlien, M. dan V.M.A. Nurgiartiningsih. 2015. Utilization of papaya leaf waste in the form of flour and juice to improve Arabian chicken production performance. Journal of Life Science. 2(2):93100.

North, M. O. dan D. D. Bell. 1994. Commercial Chicken Production Manual. The AVI Publishing Company, inc. New York.

NRC [National Research Council]. 1994. Nutrient Requirements of Poultry. Ed Rev ke-9. Washington DC. Academy Pr.

Parmar, S.N.S., M.S. Thakur, S.S. Tomar, dan P.V.A. Pillai. 2006. Evaluation of egg quality traits in indigenous kadaknath breed of poultry. Livestock Research and Rural Development 18(9):
Roxana, G. dan M.G. Usturoi. 2012. Effect of storage time and temperature on hen egg quality. LucrăriŞtiinţifice Seria Zootehnie 57:221-229

Senkoylu, N., H. Akyurek, E Samil, dan N. Yurdakurban. 2004. Performance and egg weight of laying hens led on the diets with various by-products oil from the oilseed extraction refinery. Pakistan Journal of Nutrition 3(1):38-42.

Sihombing, G., Avivah dan S. Prastowo. 2006. Pengaruh penambahan zeolite dalam ransum terhadap kualitas telur burung puyuh. J. Indon. Trop. Anim. Agric. 31(1): 28-31.

Stadelman, W.J dan O.J. Cotteriil. 1977. Egg Science and Technology. The 2nd Edition. The Avi Publ. Co. Inc.

Steel, C.J. dan J.H. Torrie.1995. Prinsip dan Prosedur Statistik. PT. Gramedia. Jakarta.

Timbuleng, V. J.T Laihad, J.R Leke dan C.Rimbing 2015. Pengaruh Penambahan Tepung Tomat (Solanum lycopersicum 1) terhadap Kualitas Internal telur Ayam Ras. Jurnal Zootek 35(2) :258-266.

Tugiyanti, E. dan N. Iriyanti. 2012. Kualitas eksternal telur ayam petelur yang mendapat ransum dengan penambahan tepung ikan fermentasi menggunakan isolat prosedur antihistamin. Jurnal Aplikasi Teknologi Pangan 1(2):4447.

Veena, D., R.B. Eswara, M.E. Naga, and S.A.K. Azad. 2015. A study on quality traits of chicken eggs collected in and around Gannavaram, Krishna district in different seasons. International 
Journal of Recent Science and Research 6(9): 6487-6489

Wahju, J. 1992. Ilmu Nutrisi Unggas. Gajah Mada University Press. Yogyakarta.

Yuwanta, T. 2010. Telur Dan Kualitas Telur. Gadjah Mada University Press. Yogyakarta. 